\title{
MAGISTER DIXIT: DOCÊNCIA, PESQUISA E EXTENSÃO
}

\author{
Lourenço Ocuni Cá ${ }^{1}$ \\ Cristina Mandau Ocuni Cá2
}

RESUMO: A teoria desenvolvida por Paulo Freire sobre o processo de ensino-aprendizagem abrange não somente a educação, mas também envolve contexto sociopolítico no ato de educar. A questão relacionada com a teoria de Freire foi objeto de análise com os estudantes do Curso de Ciência da Natureza e Matemática da Universidade da Integração Internacional da Lusofonia Afro-Brasileira (UNILAB) no primeiro trimestre de 2016, visando integrar os estudantes partícipes do Programa de Iniciação à Docência (PIBID-CAPES) e as práticas educativas observadas em sala de aula nos Municípios de Redenção e Acarape no Estado do Ceara. Este artigo é o resultado de investigação e problematização com os estudantes do Curso de Ciências da Natureza e Matemática da UNILAB da concepção de Freire sobre os seguintes temas geradores: educação e conscientização, o ato de ensinar, o ato de estudar, prática educativa e a tríade que compõe a universidade: a docência, pesquisa e extensão.

Palavras-chave: Paulo Freire, docência, pesquisa e extensão.

\section{MAGISTER DIXIT: TEACHING, RESEARCH AND EXTENSION}

ABSTRACT: The theory developed by Paulo Freire about the teaching-learning process covers not only education, but also involves socio-political context in the act of educating. The question related to Freire's theory was the object of analysis with the students of the Course on Nature Science and Mathematics at the University of International Integration of AfroBrazilian Lusophony (UNILAB) in the first quarter of 2016, aiming to integrate students participating in the Program of Teaching Initiation (PIBID-CAPES) and the educational practices observed in the classroom in the Municipalities of Redenção and Acarape in the State of Ceara. This article is the result of research and problematization with students of the Course of Natural Sciences and Mathematics at UNILAB of Freire's conception on the following generative themes: education and awareness, the act of teaching, the act of studying, educational practice and the triad that makes up the university: teaching, research and extension.

Keywords: Paulo Freire, teaching, research and extension

\footnotetext{
${ }^{1}$ Professor PhD. Associado da Universidade da Integração Internacional da Lusofonia Afrobrasileira (UNILAB). Email: ocuni@unilab.edu.br

${ }^{2}$ Professora doutora. Instituto Dom Jose de Educação de Educação e Cultura. Universidade do Vale do Acaraú. Email: cristina.mandau@hotmail.com
} 


\section{INTRODUÇÃO}

A teoria pedagógica de Freire mostra que novos horizontes se abrem quando as deficiências e percepções iniciais são corrigidas ou quando nova evidência é recolhida e avaliada, na aceitação do diferente. Para ele, nem todos confrontam com os mesmos desafios, nem apresentam modos ou estilos semelhantes de expressão. Considera a educação do oprimido como uma perspectiva crítica ao longo do processo educativo e dos estudos que acarretam uma progressiva descrição ou análise para uma intervenção social no processo de transformação social. Discutir com as classes sociais seus anseios, sonhos, receios e frustrações, é o modo de se trabalhar efetivamente a relação entre educação e política.

A docência precisa estar atenta que não se ensina apenas conteúdos, a sua prática deve também ensinar pensamentos críticos, em outras palavras, assumir a política da própria prática, apontando as razões do ato de ensinar-aprender.

As preocupações de Paulo Freire no que tange ao processo de ensino e aprendizagem e sua relação com a conscientização do educando são um dos focos de análise deste trabalho. O teórico instiga os educadores e educadoras a ter como um dos pontos de suas práticas educativas a necessidade de desenvolver uma atuação profissional baseada na ética para a mudança social. Essa leitura representa uma tentativa para se compreender a diretividade da educação Para a consecução da relação entre educação e política, Freire assegura que o ponto de partida de um projeto político-pedagógico tem de estar efetivamente nos níveis de aspiração, nos níveis de sonho, nos níveis de compreensão da realidade e nas formas de ação e de luta dos grupos populares e dos educandos.

\section{PROCESSO DE ENSINO-APRENDIZAGEM}

A leitura crítica da realidade tem de juntar a sensibilidade do real e, para ganhar esta sensibilidade ou desenvolvê-la, precisa da comunhão com as massas. 0 intelectual precisa saber que a sua capacidade crítica não é superior nem inferior à sensibilidade popular. A leitura do real requer as duas. Longe das massas populares, em interação apenas com seus livros, o intelectual corre o risco de ganhar uma 
racionalidade desencarnada, uma compreensão do mundo sem carne (FREIRE, 1985, p.39-40)

É preciso que educador/educadora saiba que o seu aqui e o seu agora são quase sempre lá do educando. Mesmo que o sonho do educador seja não somente tornar o seu aqui - agora, o seu saber, acessível ao educando, mas ir mais além de seu aqui - agora com ele ou compreender, que o educando ultrapasse o seu aqui, para que este sonho se realize tem que partir do aqui do educando e não do educador. No mínimo, tem de levar em consideração a existência do aqui do educando e respeitá-lo. No fundo, ninguém chega lá, partindo de lá, mas de um certo aqui. Isto significa, em última análise, que não é possível ao educador desconhecer, subestimar ou negar os saberes de experiência feitos com que os educandos chegam á escola (FREIRE, 1992, p.59).

Não há como não repetir que ensinar não é a pura transferência mecânica do perfil do conteúdo que o professor faz ao aluno, passivo e dócil. Como não há também como não repetir que, partir do saber que os educandos tenham não significa ficar girando em torno deste saber. Partir significa pôr-se a caminho, ir-se deslocar-se de um ponto a outro e não ficar, permanecer. Partir do saber de experiência feito para superá-lo não ficar nele (FREIRE, 1992, p.70).

Ler um texto é algo sério, mais demandante. Ler um texto não é "passear" licenciosamente, pachorrentamente, sobre as palavras. É apreender como se dão as relações entre as palavras na composição do discurso. É tarefa de sujeito crítico, humilde, determinado (FREIRE, 1992, p.70-77). Ler, enquanto estudo, é um processo difícil, até penoso, às vezes, mas sempre prazeroso também. Implica que o leitor ou a leitora se adentre na intimidade do texto para apreender sua mais profunda significação. Quanto mais fazemos este exercício disciplinadamente, vencendo todo desejo de fuga da leitura, tanto mais nos preparamos para tornar futuras leituras menos difíceis. Ler um texto, sobretudo, exige de quem o faz estar convencido de que as ideologias não morreram. Por isso mesmo, a de que o texto se acha empapado ou ás vezes nele se acha escondida, não é necessariamente, a de quem, vai lê-lo. Daí a necessidade que tem o leitor ou a leitora de uma postura aberta e crítica, radical e não sectária, sem a qual se fecha ao texto e se proíbe de com ele aprender algo porque o 
texto talvez defenda posições antagônicas ás do leitor ou a leitora. Às vezes, o que é irônico, as posições são apenas diferentes.

Em muitos casos nem sequer temos lido o autor. Temos lido sobre ele e, sem a ele ir, aceitamos as críticas que lhe são feitas. Assumimo-las como nossas. 0 fundamental, porém, é que não se crítica um autor pelo que dele se diz, mas pela leitura séria, dedicada, competente que fazemos dele. Sem que isto signifique não devemos ler o que dele se disse ou se diz também. A prática de ler seriamente textos termina nos ajudando a aprender como a leitura, enquanto estudo, é um processo amplo, exigente de tempo, de paciência, de sensibilidade, de método, de rigor, de decisão e de paixão de conhecer.

Um educador fundando-se em uma compreensão distorcida da conscientização e em uma visão profundamente ingênua da prática docente, vista como prática neutra, a serviço do bem-estar da humanidade, não é capaz de perceber que uma das bonitezas desta prática está exatamente em que não é possível vivê-la sem correr risco. O risco é não sermos coerentes, de falar uma coisa e fazer outra, por exemplo. E é exatamente a sua politicidade, a sua impossibilidade de ser neutra, que demanda do educador sua eticidade. A tarefa do educador seria demasiado fácil se se reduzisse ao ensino de conteúdos que nem sequer precisariam ser tratados assepticamente e assepticamente transmitidos aos educandos porque enquanto conteúdo de uma ciência neutra, já são em si assépticos. O educador neste caso não tem por que, ao menos, se preocupar ou se esforçar por ser decente, ético, a não ser quanto á sua capacitação. Sujeito de prática neutra não tem outra coisa a fazer senão transferir conhecimento também neutro.

De fato, não é isso que se dá. Não há nem jamais houve prática docente em espaço-tempo nenhum de tal maneira neutra, comprometida apenas com ideias preponderantemente abstratas e intocáveis. Insistir nisso e convencer ou tentar convencer os incautos de que essa é a verdade é uma prática política indiscutível com que se pretende amaciar a possível rebeldia dos injustiçados. Tão política quanto a outra, a que não esconde, pelo contrário, proclama, sua politicidade.

O que, sobretudo move Paulo Freire a defender a eticidade é saber que sendo a educação, por sua própria natureza, diretiva e política, deve sem jamais negar seu 
sonho ou sua utopia aos educandos, respeitá-los. Defender com seriedade, rigorosamente, mas também apaixonadamente, uma tese, uma posição, uma preferência, estimulando e respeitando, ao mesmo tempo, o direito ao discurso contrário, é a melhor forma de ensinar, de um lado, o direito de termos o dever de brigar por nossas ideias por nossos sonhos e não apenas de aprender a sintaxe do verbo haver, de outro, o respeito mútuo (FREIRE, 1992, p. 78)

No estado atual em que tudo se confunde, se as crianças e jovens têm determinado tipo de relacionamento com os progenitores ou padrões de comportamento familiar (desadequação ou não, por agora não interessa), acham legitimo reproduzi-los na escola, tida como uma extensão da família. Há nisto culpas da própria escola e de todo o sistema educativo (RIBEIRO, 2004, p.55)

Respeitar os educandos, porém, não significa mentir a eles sobre seus sonhos, dizer-Ihes com palavras ou gestos ou práticas que o espaço da escola é um lugar sagrado onde apenas se estuda e estudar não tem a ver com o que se passa no mundo lá fora; esconder deles as suas opções, como se fosse pecado preferir, optar, romper, decidir, sonhar. Respeitá-los significa, de um lado, testemunhar a eles a sua escolha, defendendo-a; de outro, mostrar-Ihes outras possibilidades de opção, enquanto ensino, não importa o quê.

É a mesma reflexão que nos impomos com relação à alfabetização. Quem procura cursos de alfabetização de adultos quer aprender a escrever e a ler sentenças, frases, palavras, quer alfabetizar-se. A leitura e a escrita das palavras, contudo, passa pela leitura do mundo. Ler o mundo é um ato anterior à leitura da palavra. O ensino da leitura e da escrita da palavra a que falte o exercício crítico da leitura e da releitura do mundo é, científica, política e pedagogicamente, capenga. Há riscos de influenciar os alunos? Não é possível viver, muito menos existir, sem riscos. O fundamental é nos prepararmos para saber corrê-los bem. Qualquer que seja a qualidade da prática docente, autoritária ou democrática, ela é sempre diretiva. No entanto, a diretividade do educador interfere na capacidade criadora, formuladora, indagadora do educando, de forma restritiva, então a diretividade necessária se converte em manipulação, em autoritarismo. Manipulação e autoritarismo praticados por muitos educadores que, dizendo-se de si mesmos progressistas (FRIERE, 1992, p.78-79) 
A teoria de aprendizagem de Freire, disse-se, mais ou menos, nos anos 70 (1970), está subordinada a propósitos sociais e políticos e uma teria assim, se expõe aos riscos da manipulação, como se houvesse a possibilidade de uma prática educativa em professores e professoras, alunos e alunas pudessem estar absolutamente isentos do risco da manipulação e de suas consequências. Como se fosse ou tivesse sido possível, em algum tempo-espaço, a existência de uma prática educativa distante, fria, indiferente, com relação a propósitos sociais e políticos (FREIRE, 1992, p. 80).

O que se exige eticamente de educadores e educadoras progressistas é que, coerentes com seu sonho democrático, respeitem os educandos e jamais, por isso mesmo, os manipulem. Daí a vigilância com que devem atuar, com que devem viver intensamente sua prática educativa; daí seus olhos devendo estar sempre abertos, seus ouvidos, também, seu corpo inteiro aberto às armadilhas de que o chamado currículo oculto, ainda está cheio. Daí a exigência que se devem impor de ir tornandose cada vez mais tolerantes, de ir pondo-se cada vez mais transparentes, de ir virando cada vez mais críticos, de ir fazendo-se cada vez mais curiosos.

Quanto mais tolerantes, quanto mais transparentes, quanto mais críticos, quanto mais curiosos e humildes, tanto mais assumem autenticamente a prática docente. Numa tal perspectiva, indiscutivelmente progressista, muito mais pósmoderna, como se entende a pós-modernidade, que moderna, e nada modernizante, ensinar não é simples transmissão do conhecimento em torno do objeto ou conteúdo. Transmissão que se faz muito mais através da pura descrição do conceito do objeto a ser mecanicamente memorizado pelos alunos. Ensinar ainda do ponto de vista pós modernamente progressista de que Freire trata aqui, não pode reduzir-se a um mero ensinar os alunos a aprender através de uma operação em que o objeto do conhecimento fosse $o$ ato mesmo de aprender. Ensinar a aprender ao aprender a razão de ser o objeto ou conteúdo. É ensinando a biologia ou outra disciplina qualquer que o professor ensina os alunos a aprender.

Na linha progressista, ensinar implica, pois, que os educandos, em certo sentido, penetrando o discurso do professor, se apropriem da significação profunda do conteúdo sendo ensinado. O ato de ensinar, vivido pelo professor ou professora, vai desdobrando-se, da parte dos educandos, no ato de conhecerem o ensinado. 0 
professor só ensina em termos verdadeiros na medida em que conhece o conteúdo que ensina, quer dizer, na medida em que se apropria dele, em que o apreende. Neste caso, ao ensinar, o professor re-conhece o objeto já conhecido. Em outras palavras, refaz a sua cognoscitividade na cognoscitividade dos educandos. Ensinar é assim a forma que toma o ato de conhecimento que o professor necessariamente faz na busca de saber o que ensina para provocar nos alunos seu ato de conhecimento também. Por isso, ensinar é um ato criador, um ato crítico e não mecânico. A curiosidade do professor e dos alunos, em ação, se encontra na base do ensinar-aprender. Ensinar um conteúdo pela apropriação ou a apreensão deste por parte dos educandos demanda a criação e o exercício de uma séria disciplina intelectual a vir sendo forjada desde a préescola. Pretender a inserção crítica dos educandos na situação educativa, enquanto situação de conhecimento, sem essa disciplina, é espera vã. Mas, assim como não é possível ensinar a aprender, sem ensinar um certo conteúdo através de cujo conhecimento se aprende a aprender, não se ensina igualmente a disciplina de que Freire trata a não ser na e pela prática cognoscente de que os educandos vão se tornando sujeitos cada vez mais críticos (FREIRE, 1992, p. 82).

$\mathrm{O}$ ato de estudar de compreender, de conhecer, de ensinar, como um puro entretenimento, uma espécie de brinquedo com regras frouxas ou sem elas, nem tampouco com um que-fazer insosso, desgostoso, enfadonho. $\mathrm{O}$ ato de estudar, de ensinar, de aprender, de conhecer é difícil, sobretudo exigente, mas prazeroso, como sempre nos adverte Georges Snyders (1986 apud FREIRE, 1992) É preciso, pois que os educandos descubram e sintam a alegria nele embutida, que dele faz parte e que está sempre disposta a tomar todos quantos a ele se entreguem.

O papel testemunhal do professor na gestão desta disciplina é enorme. Mais uma vez aí, a sua autoridade, de que sua competência faz parte, joga importante função. Um professor que não leva a sério sua prática docente, que, por isso mesmo não estuda e ensina mal, o que mal sabe que não luta para que disponha de condições materiais indispensáveis á sua prática docente, se proíbe de concorrer para a formação da imprescindível disciplina intelectual dos estudantes. Anula-se, pois, como professor. 
Essa disciplina não pode resultar de um trabalho feito nos alunos pelo professor. Requerendo, embora, a presença marcante do professor ou da professora, sua orientação, seu estímulo, sua autoridade, essa disciplina têm de ser construída e assumida pelos alunos.

Não podemos deixar de lado, desprezado como algo imprestável, o que educandos, sejam crianças chegando à escola ou jovens e adultos a centros de educação popular, trazem consigo de compreensão do mundo, nas mais variadas dimensões de sua prática na prática social de que fazem parte. Sua fala, sua forma de contar, de calcular, seus saberes, em torno do chamado outro mundo, sua religiosidade, seus saberes em torno da saúde, do corpo, da sexualidade, da morte, da força dos santos, dos conjuntos.

Esse é, aliás, um dos temas fundamentais da etnociência, hoje, o de como evitar a dicotomia entre esses saberes, o popular e o erudito ou o de como compreender e experimentar a dialética entre o que (SNYDERS, 1986 apud FREIRE, 1992, p. 86) chama cultura primeira e cultura elaborada.

O respeitar esses saberes se insere no horizonte maior em que eles se geram o horizonte do contexto cultural, que não pode ser entendido fora de seu corte de classe, até mesmo em sociedade de tal forma complexas em que a caracterização daquele corte é menos facilmente apreensível. O respeito, então, ao saber popular implica necessariamente o respeito ao contexto cultural. A localidade dos educandos é o ponto de partida para o conhecimento que eles vão criando do mundo. Seu mundo, em última análise, é a primeira e inevitável face do mundo mesmo.

Paulo Freire responde em Pedagogia da esperança(1992), as críticas feitas em Pedagogia do oprimido (1987), a vaguidade do conceito do oprimido como do de povo, a afirmação que faz no livro de que o oprimido, libertando-se, liberta ao opressor, o não haver, como antes sublinhado, declarado que a luta de classes é o motor da história, o tratamento que dá ao indivíduo, sem aceitar reduzi-lo a puro reflexo das estruturas socioeconômicas, o tratamento que dá à consciência, à importância da subjetividade, o papel da conscientização que na Pedagoga do oprimido supera, em termos de criticidade, a o ela atribuído em Educação como prática da liberdade (1975); a asserção de que a aderência à realidade em que se 
encontram as grandes massas camponesas da América Latina está a exigir que a consciência de classe oprimida passe, senão antes, pelo menos concomitantemente pela consciência de homem oprimido (FREIRE, 1987)

\section{NEOLIBERALISMO E EDUCAÇÃO}

O termo liberalismo surgiu no Séc. XVIII, com Adam Smith (1723-1790). Smith defendia as seguintes ideias: a fonte de toda riqueza é o trabalho; uma feliz organização da economia realiza-se espontaneamente em toda sociedade em que o homem pode conduzir-se sob impulso de seus interesses pessoais: os governos devem conceder liberdade total à produção nacional e ao comércio internacional. Smith preconiza também a não intervenção do Estado e o livre-câmbio. Nasceram a partir daí duas vertentes: a econômica - o Estado não deve atuar no mercado e a política - que preconiza o liberalismo igualitário, as liberdades individuais como forma de obter a justiça social. Para Smith, a força motriz do lucro conduz a economia a resultado eficiente, como se esta fosse guiada por uma espécie de mão invisível (CÁ, 2008, p.152-153).

A vertente neoliberal deve ter surgido nas duas vertentes de Smith e seus defensores como, por exemplo, Hayek e Friedman. O primeiro é considerado uma das principais figuras do chamado neoliberalismo econômico. Em seu livro Caminho da Servidão publicado em 1944, ele refere-se ao neoliberalismo como conjunto de correntes de pensamento bastante diverso, cujo traço comum é o respeito pela pessoa humana e a utilização da iniciativa individual como base econômica, tendo em vista que o mecanismo dos preços, funcionando como mercado livre permite um aproveitamento melhor dos recursos naturais e dos meios de produção.

Friedman aquiescia com Hayek ao afirmar que a liberdade individual é a finalidade das organizações sociais, que o Estado é necessário para preservar a liberdade. Em seu livro Capitalismo e Liberdade enfatiza o papel do capitalismo competitivo, a organização da maior parte da atividade econômica através da empresa privada, operando em um mercado livro, como sistema de liberdade econômica e condição necessária para a liberdade política (CÁ, 2008, p.154-155). 
O neoliberalismo por ser um sistema do qual não se importa com os direitos sociais, trata o processo educativo como um mercado, ou seja, um bem de consumo que pode ser comercializado, tal como um outro serviço privativo qualquer, também tenta fazer com que as instituições educativas sejam um meio de transmissão dos princípios do neoliberal Os defensores da política neoliberal ignoram todos os protestos contra o neoliberalismo. Então, tentam enquadrar e controlar as práticas pedagógicas das escolas e das instituições de ensino para que continuem veiculam os princípios neoliberais dominantes, que são formar pessoas e realizar pesquisas e estudos, apenas para suprir as necessidades de mercado e construir instituições de ensino apenas visando a formação de profissionais que atendam uma determinada demanda, ignorando o ponto de vista social e cultural do cidadão.

Por equipararem as instituições de ensino como empresas, o sistema neoliberal é totalmente contrário às entidades públicas, por considerá-las ineficazes e ineficientes. O discurso neoliberal condena também o corporativismo em tais entidades considera-as como sendo uma máfia ou um cartel. Ataca a falta de produtividade das pesquisas acadêmicas entendendo-se que não são rentáveis a não ser para a própria universidade e ataca os direitos trabalhistas e de reivindicações. Outro ponto criticado é a importância que a universidade pública dá a áreas humanas, por serem cursos que não têm muita importância para o mercado de trabalho, sendo considerados inúteis à produção industrial, pois para o neoliberalismo não interessa a cultura de um povo, e sim, sua mão de obra e seu conhecimento em áreas lucrativas para gerar desenvolvimento ao seu país.

A universidade pública é vista como uma empresa mal administrada, pois seus gastos poderiam ser menores, se houvesse menos desperdício. É proposto então que os próprios estudantes arquem com os custos de ensino nas universidades. Outra pretensão seria novo tipo de contrato de trabalho no qual tende eliminar a dedicação exclusiva de professores e ampliar o quadro de professores de tempo parcial e que as próprias universidades busquem recursos financeiros para as suas pesquisas nas empresas industriais e comerciais, obrigando-as então a responder as demandas do mercado e fazer pesquisas aplicadas para que as universidades funcionem à semelhança do mercado. 
As escolas públicas também são criticadas pelo neoliberalismo por serem empresas mal administradas além de usar métodos atrasados, ignorando completamente as diferenças sociais e econômicas. As escolas públicas deveriam ser privatizadas, portanto, funcionariam como as escolas particulares assim resolveriam as questões administrativas e transformariam os problemas da educação em questão de mercado. Esta análise se dá pelo ponto de vista, de que os alunos podem se transformar em clientes.

É proposto então que se privatizem as escolas, para que elas possam competir no mercado, melhorando assim a qualidade do ensino e a funcionar a semelhança do mercado.

Vivemos em um mundo em que as competências são ferozes, e falam mais alto que nossa solidariedade e cidadania; não devemos formar um cidadão em uma especialidade, pois o mesmo só se tornaria apenas mais uma máquina descartável, pois não teria uma personalidade. Deve-se analisar que o excesso de competitividade e de especialização prematuro impossibilita o indivíduo de ter qualquer tipo de vida sociocultural. Deve-se também se pensar que é preciso deixar o homem conciliar seus sentimentos, pensamentos, valores e atos a fim de se formar para ajudar sua comunidade e o seu progresso e não apenas mais uma peça ou engrenagem na produção industrial mundial.

Daí que, a linguagem da possibilidade, que comporta a utopia como sonho possível prefiram o discurso neoliberal, pragmático, segundo o qual devemos nos adequar aos fatos como estão se dando, como se não pudessem dar-se de outra forma, como se não devêssemos lutar, precisamente porque mulheres e homens, para que se dessem de outra maneira (FREIRE, 1992, p.90).

$\mathrm{Na}$ verdade, toda vez que o futuro seja considerado como um pré-dado, ora porque seja a pura repetição mecânica do presente, só adverbialmente mudado, ora porque seja o que teria de ser, não há lugar para utopia, portanto, para o sonho, para a opção, para a decisão, para a espera na luta, somente como existe esperança. Não há lugar para a educação. Só para adestramento.

A modernidade de alguns setores das classes dominantes, em cuja posição supera de longe a postura de velhas e retrógradas lideranças dos chamados 'capitães 
de indústria' de outrora não poderia, porém, mudar a sua natureza de classe. Isso não significa, todavia, que as classes trabalhadoras, para Freire, devem fechar-se sectariamente à ampliação de relações entre elas e as classes dominantes. 0 importante, porém, é que as classes trabalhadoras continuem aprendendo na própria prática de sua luta a estabelecer os limites para as suas concessões, o que vale dizer, que, ensinem as dominantes, os limites em que elas se podem mover (FREIRE, 1992, p.93).

A modernidade não tem a força suficiente para acabar com as classes sociais e decretar a inexistência de interesses antagônicos entre discursos neoliberais, como não tem força para acabar com os conflitos e a luta entre elas. O que acontece é que a luta é uma categoria histórica. Tem, por isso, historicidade. Muda de espaço-tempo a espaço-tempo. A luta não nega a possibilidade de acordos, de acertos entre as partes antagônicas. Os acordos fazem parte igualmente da luta.

Houve o esfacelamento do chamado socialismo realista não significa de um lado, que foi o socialismo mesmo que se revelou inviável; de outro, que o capitalismo se afirmou definitivamente na sua excelência. Que excelência é essa que consegue conviver com mais de um bilhão de habitantes do mundo em desenvolvimento que vivem na pobreza, para não falar em miséria. Para não falar também na quase indiferença com que convive com bolsões de pobreza e bolsos de miséria no seu próprio corpo, o desenvolvido. Que excelência é essa, que dorme em paz com a presença de um sem número de homens e mulheres cujo lar é a rua, deles e delas ainda se diz que é a culpa de na rua estarem.

Que excelência é essa que pouco ou quase nada luta contra as discriminações de sexo, de classe, de raça, como se negar o diferente, humilhá-lo, ofendê-lo, menosprezá-lo, explorá-lo fosse um direito dos indivíduos ou classes, ou das raças ou de sexo em posição de poder sobre o outro. Que excelência é essa que registra nas estatísticas, momentaneamente, os milhões de crianças que chegam ao mundo e não ficam e, quando ficam, partem cedo, ainda crianças e, se mais resistentes, conseguem permanecer, logo do mundo se despedem (FREIRE, 1992).

Que excelência é essa que, no Nordeste brasileiro, convive com uma exacerbação tal da miséria que parece mais ficção: meninos e meninas, mulheres, 
homens, disputando com cachorros famintos, tragicamente, animalescamente detritos nos grandes aterros de lixo, na periferia das cidades, para comer. E São Paulo não escapa à experiência dessa miséria (FREIRE, 1992, p.96). Que excelência é essa que parece não ver meninos barrigudos, comidos de vermes, mulheres desdentadas, aos 30 anos parecendo velhas alquebradas, homens gastos, populações diminuindo de porte. Cinquenta e dois por cento da população do Recife favelada, vítima fácil das intempéries, das doenças que abatem sem dificuldade os corpos enfraquecidos. Que excelência é essa que vem compactuando com o assassinato frio, covarde, de camponeses e camponesas, sem-terra, porque lutam pelo direito à palavra e a seu trabalho à terra ligado e pelas classes dominantes dos campos espoliados.

Que excelência é essa que não se comove com o extermínio de meninas e meninos nos grandes centros urbanos brasileiros; que proíbe que 8 milhões de crianças populares se escolarizem, que expulsa das escolas, grande parte das que conseguem entrar e chama a tudo isso modernidade capitalista? (FREIRE, 1992, p.96)

O sonho pela humanização, cuja concretização é sempre processo, e sempre devir, passa pela ruptura das amarras reais, concretas, de ordem econômica, política, social, ideológica e que nos estão condenando á desumanização. O sonho é assim uma exigência ou uma condição que se vem fazendo permanentemente na história que fazemos e que nos faz e refaz (FREIRE, 1992, p.99).

É por isso que, como indivíduo e como classe, o opressor não liberta nem se liberta. É por isso que, libertando-se na e pela luta necessária e justa, o oprimido, como indivíduo e como classe, liberta o opressor, pelo fato simplesmente de proibi-lo de continuar oprimindo (FREIRE, 1987). É preciso juntar a ela a luta política pela transformação do mundo. A libertação dos indivíduos só ganha profunda significação quando se alcança a transformação da sociedade (FREIRE,1992, p. 100).

Na percepção dialética, o futuro com que sonhamos não é inexorável. Temos de fazê-lo, de produzi-lo, ou não virá da forma como mais ou menos queríamos. É bem verdade que temos de fazê-lo não arbitrariamente, mas com os materiais concretos de que dispomos e mais com o projeto com o sonho por que lutamos.

Enquanto para as posições dogmáticas, mecanicistas, a consciência crítica toma forma como uma espécie de epifenômenos, como resultado automático e mecânico 
de mudanças estruturais; para a dialética, a importância da consciência está em que, não sendo a fazedora da realidade, não é, por outro lado, puro reflexo seu. É exatamente neste ponto que se coloca a importância fundamental da educação enquanto ato de conhecimento, não só de conteúdo, mas dá razão de ser dos fatos econômicos, sociais, políticos, ideológicos, históricos, que explicam o maior ou menor grau de interdição do corpo consciente a que estejamos submetidos (FREIRE, 1992, p. 102)

Segundo Freire (1992) do ponto de vista do dogmatismo mecanicista, não temos como sequer falar em conscientização. Daí que as lideranças dogmáticas, autoritárias, não tenham por que dialogar com as classes populares, mas dizer-lhes o que devem fazer. Mecanicista e idealistamente é impossível entender o que se passa nas relações de opressor com oprimido como indivíduos ou como classe. Só entendimento dialético, como se dão consciência no mundo, é possível compreender o fenômeno da introjeção do opressor pelo oprimido, a aderência deste aquele, a dificuldade de que o oprimido de localizar o opressor fora de si, oprimido. É isto o que os mecanicistas dogmáticos, autoritários, sectários, não percebem e recusam quase sempre como idealismo.

É a leitura do mundo exatamente a que vai possibilitando a decifração cada vez mais crítica da ou das situações-limites, mais além das quais se acha o interdito viável. É preciso, porém, deixar claro que, em coerência com a posição dialética em que se põe em que se percebe as relações do mundo-consciência-prática-leitura-do-mundoleitura-da-palavra-contexto-texto, a leitura do mundo não pode ser a leitura dos acadêmicos imposta às classes populares. Nem tampouco pode tal leitura reduzir-se a um exercício complacente dos educadores em que, como prova de respeito à cultura popular, silenciem em face do saber de experiência feito e a ele se adaptem.

Entender o sentido de festas da cultura popular no corpo da cultura de resistência, sentir sua religiosidade de forma respeitosa, numa perspectiva dialética e não apenas como se fosse expressão pura de sua alienação. Respeitá-la como direito seu. Não importa que pessoalmente a recuse de modo geral, ou que não aceite a forma como é ela experienciada pelo grupo popular. 


\section{PESQUISA E EXTNSÃO}

A palavra universidade de acordo com várias concepções, qualidade ou u de universal, instituição de ensino e pesquisa constituída por um conjunto de faculdades e escolas destinadas a promover a formação profissional e científica de pessoal de nível superior, e a realizar pesquisa teórica e prática nas principais áreas do saber humanístico, tecnológico e artístico e a divulgação de seus resultados à comunidade científica mais ampla. A universidade abrangente por conseguinte, o conjunto das edificações e instalações físicas nas quais funciona. Ela é composta para o seu funcionamento de pessoal docente, discente e técnicos administrativo. A palavra universidade é de origem latina e remonta os séculos XII a XIV e constitui um espaço do saber que tem a função de formar os cidadãos para as diversas atividades na sociedade.

Segundo Freire (1992) a universidade é um tripé que abrange a docência, a pesquisa e a extensão, onde os três constituem um ciclo contínuo de conhecimento. A universidade de antigamente que era centrada na política do boi, onde somente os filhos dos ricos entravam, difere muito da concepção de universidade que é adotada atualmente onde o saber é "liberado" a qualquer pessoa de direito. O ciclo da universidade é fundamentado em dois momentos, o momento em que conhecemos o conhecimento existente (docência) e o momento em que produzimos o novo conhecimento (Pesquisa), em que o momento pesquisa-docência interage entre si de forma continua e sem oscilações classicistas.

É importante destacar que a vivacidade do discurso, a leveza da oralidade, a espontaneidade do diálogo, em si mesmos, não sacrificam em nada a seriedade de nenhuma obra científica ou a sua necessária rigorosidade. Haveria quem pensasse ingenuamente que o rigor na análise só existe quando o pesquisador se fecha em quatro paredes, por trás de uma porta bem segura, fechada com enorme chave. Só aí, na intimidade silenciosa dos livros ou dos laboratórios, seria possível a seriedade científica.

Isso ocorreria com igual relevo na atividade docente como na pesquisa em que se tenta evitar qualquer dicotomia que, no fundo, prejudica a ambas, como por outro lado, nas atividades de extensão. Na verdade, se não em todas, mas em grande parte 
delas, se busca igualmente inovar na chamada extensão que, em lugar de se limitar a uma ida puramente assistencial da universidade a áreas populares tornar-se-ia um meio através do qual a universidade procuraria encontrar-se com os movimentos sociais, os grupos populares. E esse encontro se estaria dando também na intimidade da universidade mesma e não só nas áreas populares. Paulo Freire se recorda das discussões sobre a questão política tanto quanto epistemológica envolvidas neste problema (FREIRE, 1992, p.191-192)

A decisão política, de caráter progressista, mas que jamais deveria se alongar em populismo, de pôr-se a universidade a serviço também dos interesses populares e a necessária implicação, na prática, de uma compreensão crítica em torno de como se deve relacionar a ciência universitária com a consciência das classes populares. No fundo, a relação entre saber popular, senso comum e conhecimento científico.

Freire Insiste nessa relação entre o senso comum e o conhecimento científico; observa no saber científico, um determinado poder autoritário. O saber científico, considerado por todos nós como saber, leva-nos a considerá-lo um saber em nós mesmos. Ele nos torna poderosos e, como tal, autoritários. Através dessa concepção do saber como poder, vemos claramente como a estrutura social pode ser explicada a partir de lutas pelo poder, de poderes distintos, em que uma parte desse poder ou desses poderes que aparecem na sociedade corresponderia ao intelectual, pelo fato de que ele detém o saber científico. Esse intelectual menospreza o saber que não é científico e, inconscientemente, o saber popular; para o intelectual político, o senso comum popular mostra-se como um não-saber e, enquanto não-saber, como um nãopoder (FREIRE, 1985, p.57)

Na medida em que as massas não detêm o saber que o intelectual possui, elas não detêm o poder. E esse desprezo pelo saber popular afasta o intelectual das massas. Uma das coisas que o intelectual deva aceitar é que esse saber popular é de uma riqueza sociológica fundamental para qualquer ato político, para qualquer ato de transformação da sociedade.

$\mathrm{Na}$ acepção de Freire (1985), a primeira coisa que um intelectual progressista deve fazer, se quer juntar-se às massas, é respeitar esse saber e procurar apropriar-se do sentimento, deste sentir, deste atuar das massas, que se manifesta 
fundamentalmente através da resistência ou das expressões culturais de resistência. Esta apropriação poderia, então, permitir ao intelectual propor seu saber científico recebendo, por sua vez, a sensibilidade das massas. E as massas poderiam apropriar-se desse saber científico, não da maneira como é formulado pelo intelectual, mas transformando-o. O saber científico transforma-se em científico apenas à medida que ele se apropria do saber popular. E o saber popular se transforma em um saber de ação e transformação eficaz quando se apropria, por sua vez, de forma criativa, deste saber científico proposto pelo intelectual.

Dessa forma se dá a união entre teoria e prática. Essa compreensão científica do mundo, essa compreensão coerente e unitária do mundo, que é o rigor do pensamento filosófico, deve adquirir (e somente adquire) sentido quando se preenche com esse outro conhecimento, porque esse outro conhecimento é o elemento outro, é o não Eu, é o Outro, que vai transformar a totalidade do mundo. Separadas, são realidades independentes; unidas, são realidades em que a totalidade se manifesta através dessa união. A união entre o saber científico e o senso comum é fundamental para qualquer concepção de luta política, de educação, de processo educativo (FREIRE, 1985).

Para Paulo Freire, não há dúvida em nenhum momento de que quando pensamos, em termos críticos, em universidade e classes populares, de modo algum estarmos admitindo que a universidade deva fechar suas portas a qualquer preocupação rigorosa que deva ter com relação à pesquisa e à docência

Não faz parte da natureza de sua relação ou de seu compromisso com as classes populares a sua falta de rigor, na incompetência. Pelo contrário, a universidade que não luta por mais rigorosidade, por mais seriedade no âmbito da pesquisa como no da docência, sempre indicotomizáveis, esta sim, não pode se aproximar seriamente das classes populares, comprometer-se com elas.

No fundo, a universidade tem de girar em torno de duas preocupações básicas, de que se derivam outras e que têm que ver com o ciclo do conhecimento. Este, por sua vez, tem apenas dois momentos que se relacionam permanentemente: a) um é o momento em que conhecemos o conhecimento existente, produzido; b) o outro, o em que produzimos o novo conhecimento, como vimos anteriormente. Ainda que insista 
na impossibilidade de separarmos mecanicamente um momento do outro, ainda que enfatize que são momentos de um mesmo ciclo, parece a Paulo Freire importante salientar que o momento em que conhecemos o conhecimento existente é preponderantemente o da docência, o de ensinar e aprender conteúdos; e o outro, o da produção do novo conhecimento, é preponderantemente o da pesquisa. Na verdade, porém, toda docência implica pesquisa e toda pesquisa implica docência. Não há docência verdadeira em cujo processo não se encontre a pesquisa como pergunta, como indagação, como curiosidade, criatividade, assim como não há pesquisa em cujo andamento necessariamente não se aprenda porque se conhece e não se ensine porque se aprende.

As universidades com cujos reitores Paulo Freire esteve na Argentina em 1973, em Buenos Aires, estavam convencidos da dissociabilidade de ensino, pesquisa e extensão. Nenhuma delas estava pretendendo reduzir a democratização de si mesma ao tratamento simplista do saber. Não era isso o que as engajava, mas, na verdade, diminuir a distância entre universidade ou o que nela se faz e as classes populares sem a perda, contudo, da seriedade e do rigor. Outro aspecto a que os reitores e seus assessores deram igual atenção, no campo da docência, foi a busca de uma compreensão interdisciplinar e não puramente disciplinar do ensino.

Departamentos de diferentes faculdades ensinavam trabalhos assim na tentativa de superação das visões compartimentadas a que submetemos a realidade e em que, não raro, nos perdemos. Tudo, porém, não era rosas. As reações óbvias partiam dos sectários que, enraizados em sua verdade, jamais admitem nada que as possa abalar. Sectários de direita ou de esquerda, iguais na sua capacidade de odiar o diferente, intolerantes, proprietários de uma verdade de que não se pode ligeiramente sequer duvidar, quanto mais negar.

O aprendizado, afinal, de que em uma nova prática democrática, é possível ir aprofundando os espaços para os pactos entre as classes e ir consolidando o diálogo entre diferentes. Vale dizer, ir aprofundando-se as posições radicais e superando-se as sectárias.

É fundamental para uma ciência da globalidade não separar a sociedade global em dois mundos: o mundo da episteme e o da doxa, o mundo da filosofia e o do saber 
popular, como que se negando um ao outro, antagônicos. Se é uma ciência da globalidade, deve ser da globalidade, isto é, dos dois mundos, e procurar uni-los através da prática e da teoria. Em termos atuais, equivaleria a superar a separação entre a teoria e a prática, entre o rigor e a ingenuidade. Assim, haveria uma união desses dois elementos, uma ruptura, portanto, da separação que remonta ao princípio do conhecimento filosófico, é fundamental para qualquer compreensão profunda da realidade e para que essa compreensão possa resultar numa transformação da realidade. Porque nem a ingenuidade, nem a espontaneidade, nem o rigor científico vão transformar a realidade (FREIRE, 1985, p.60-61).

A transformação da realidade implica a união desses dois saberes, para alcançar um saber superior que é verdadeiro saber que pode transformar-se em ação e em transformação da realidade. A separação de ambos é a eliminação de toda possibilidade de compreensão da globalidade e de transformação da globalidade. 0 grande desafio que enfrentamos como intelectuais é escapar à nossa concepção de que saber científico é igual a poder e escapar ao nosso autoritarismo ao impor às massas este caminho ou simplesmente renunciar a isso, porque o caminho não está aí, e escapar também a esta outra posição: vamos às massas, esqueçamo-nos da ciência e da teoria e adotemos um pragmatismo, um empirismo que possa nos aproximar das massas. Este último caminho nos deixaria nesse espontaneismo das massas, sem poder para transformar a realidade na medida em que não utilizamos esses dois

elementos fundamentais: episteme e doxa. Este é um desafio aos intelectuais, principalmente nessa sociedade globalizada.

\section{CONSIDERAÇÕES FINAIS}

A decisão política de pôr-se a universidade a serviço também dos interesses populares é a necessária implicação, na prática, de uma compreensão clara em torno de como se deve relacionar a ciência universitária com a consciência das classes populares. De fato, a relação entre saber popular, senso comum e conhecimento científico. Há que insistir nessa relação entre o senso comum e o conhecimento científico; embora se observe no saber científico, um determinado poder autoritário. 0 saber científico, considerado por todos nós como saber, leva-nos a considerá-lo um 
saber em nós mesmos. Torna-nos poderosos e, como tal, autoritários. Através dessa concepção do saber como poder, vemos claramente como a estrutura social pode ser explicada a partir de lutas pelo poder, de poderes distintos, em que uma parte desse poder ou desses poderes que aparecem na sociedade corresponderia ao intelectual, pelo fato de que ele detém o saber científico. Esse intelectual menospreza o saber que não é científico e, inconscientemente, o saber popular; para o intelectual político, o senso comum popular mostra-se como um não-saber e, enquanto não-saber, como um não-poder

\section{REFERÊNCIAS}

CÁ, Lourenço Ocuni. A contribuição de Paulo Freire na organização do sistema educacional na Guiné-Bissau. Rio de Janeiro: Publit/EdUFMT, 2007.

CÁ, Lourenço Ocuni. A constituição da política do currículo na Guiné-Bissau e o mundo globalizado. Cuiabá: EdUFMT, 2008.

BRANDÃO, Carlos Rodrigues. O que é método Paulo Freire? São Paulo: Brasiliense, 1993.

FREIRE, Paulo. Educação como prática da liberdade. Rio de Janeiro: Paz e Terra, 1975.

FREIRE, Paulo. Pedagogia da autonomia: saberes necessários à prática docente. São Paulo: Paz e Terra, 1996.

FREIRE, Paulo. Pedagogia da esperança: um reencontro com a pedagogia do oprimido. Rio de Janeiro: Paz e Terra, 1992.

FREIRE, Paulo. Pedagogia do oprimido. Rio de Janeiro: Paz e Terra,1987.

FREIRE, Paulo. Por uma pedagogia da pergunta. Rio de Janeiro: Paz e Terra, 1985. 
FRIEDMAN, Milton. Capitalismo e Liberdade. São Paulo: Artenova S/A, 1977.

HAYEK, Frederick. Caminho da Servidão. São Paulo: Globo, 1977.

HARVEY, David. A condição pós-moderna. São Paulo: Edições Loyola, 1992.

RIBEIRO, Gabriel Mithá. A pedagogia da avestruz: testemunho de um professor. Lisboa: Gradiva, 2004.

SOARES, Magda. Linguagem e Escola: uma perspectiva social. São Paulo: Ática Editora, 1993.

Recebido em 25 de Abril de 2020.

Aprovado em 12 de maio de 2020 